\title{
Synthesis and Antitumor Activity of Novel 4,5-Disubstituted Triazole Derivatives
}

\author{
W.Y. YUAN, Y.N. WEN, N.N. Liu \& Q.P. WU* \\ School of Chemical Engineering and Environments, Beijing Institute of Technology, Beijing, China
}

ABSTRACT: A series of 4,5-disubstituted triazole derivatives $(\mathbf{5 a - - 5 d})$ were prepared starting from substituted aniline via aminolysis reaction, cyclisation, alkylation, deprotection. All the synthesized compounds were screened for cytotoxic activity against three human cancer cell lines such as MCF-7, Hela and A549. Compound $\mathbf{5 b}$ was found to be most active with $\mathrm{IC}_{50}$ values $7.20 \mu \mathrm{M}$ and $7.31 \mu \mathrm{M}$ against MCF-7 and $\mathrm{A} 549$, respectively.

KEYWORD: triazole; antitumor

\section{INTRODUCTION}

Cancer is the second leading cause of death worldwide[1] and thus discovery and development of suitable agents possessing novel mechanism of action is highly desirable to treat various types of cancer. Since Sharpless and his coworkers' report on the "click chemistry" [2]---copper (I)-catalyzed azide alkyne cycloaddition (CuAAC), 1,2,3-triazole has emerged as one of the most important heterocycles

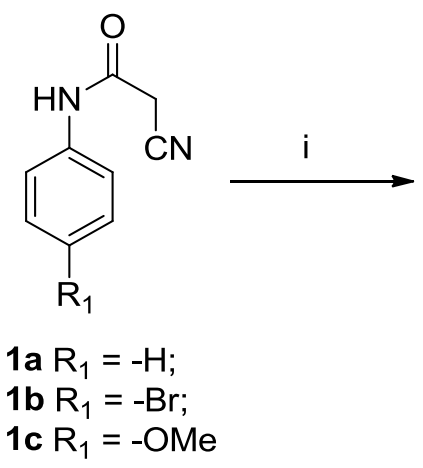<smiles>[R]c1ccc(CBr)c([R12]#N)c1</smiles>

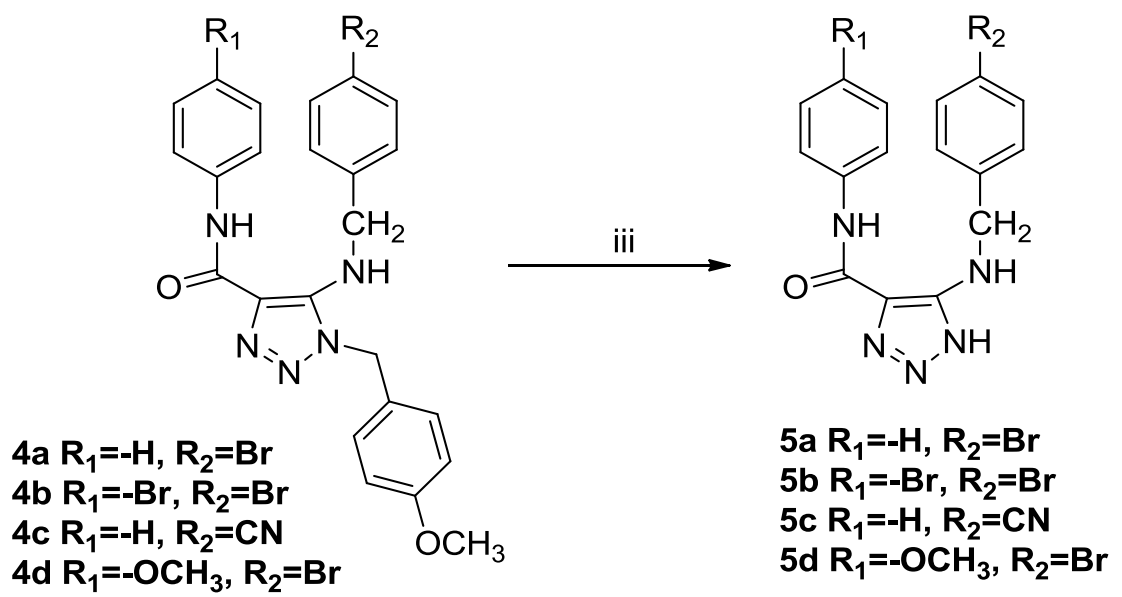


in current medicinal chemistry[3] and its applications have also been extended to widespread drug discovery.[4] [5] On the other hand, 1,2,3triazoles present a great stability under acidic, basic, and oxidative conditions.[6] A number 1,2,3-triazole derivatives show good or excellent anticancer activity. [7]

\section{RESULTS AND DISCUSSION}

Treatment of cyanoacetamide 1a-1c with 4-methoxy benzylazide forms the desired amino triazole ring 2a-2c in good yields. Alkylation of the amino group in compound $\mathbf{2 a - 2 c}$ with benzyl bromide was performed to give 4a-4c. Removal of 4methoxybenzyl group with trifluoroacetic acid generated the target compounds 5a-5d in $36-47 \%$ total yields.

The cytotoxicity of all the above compounds against three human cancer cell lines namely, A549Lung, MCF-7-Breast, and HeLa-Cervical was screened (Table 1). After exposure of cells to the test compounds for $72 \mathrm{~h}$, all the four compounds show cytotoxicity on the three cell lines. More specifically, compound $\mathbf{5 b}$ exhibits promising activity against all the three cell lines with $\mathrm{IC}_{50}$ values about $7 \mu \mathrm{M}$. Compound 5d shows good activity against MCF-7 cell lines with $\mathrm{IC}_{50}$ value of about $10.4 \mu \mathrm{M}$. It also showed moderate activity against Hela with $\mathrm{IC}_{50}$ value of about $27 \mu \mathrm{M}$.

Table 1 Cytotoxicity of triazole Compounds Against Cancer Cell Lines

\begin{tabular}{|c|c|c|c|}
\hline \multirow{2}{*}{ Compounds } & \multicolumn{3}{|c|}{$\mathrm{EC}_{50}(\mu \mathrm{M})^{\mathrm{b}}$} \\
\cline { 2 - 4 } & $\mathrm{MCF}-7$ & Hela & $\mathrm{A} 549$ \\
\hline $5 \mathrm{a}$ & 59.12 & 68.33 & $>100$ \\
\hline $5 \mathrm{~b}$ & 7.20 & 75.71 & 7.31 \\
\hline $5 \mathrm{c}$ & 92.5 & $>100$ & $>100$ \\
\hline $5 \mathrm{~d}$ & 10.43 & 27.52 & 61.98 \\
\hline
\end{tabular}

\section{CONCLUSION}

In conclusion, a series of novel triazole derivatives were synthesized in $36-47 \%$ yield in three steps and their antitumor activity against three human cancer cell lines was evaluated in vitro. Among them, compound $\mathbf{5 b}$ is a most potential anticancer agent. Further structure-activity studies with similar compounds are currently underway in our laboratory.

\section{REFERENCES}

[1] Parkin D. M., Bray F., Ferlay J., Pisani P., 2005, Globa cancer statistics, 2002, CA: a cancer journal for clinicians, 55, 74-108.

[2] Kolb, H. C.; Finn, M. G.; Sharpless, K. B. 2001, Click Chemistry: Diverse Chemical Function from a Few Good Reactions, Angewandte Chemie International Edition, 40, 2004-2021.

[3] Diaz, L.; Bujons, J.; Casas, J.; Llebaria, A.; Delgado, A. 2010, Click chemistry approach to new N-substituted aminocyclitols as potential pharmacological chaperones for Gaucher disease, Journal of Medicinal Chemistry, 53, 5248-5255.

[4] Colombano, G.; Travelli, C.; Galli, U.; Caldarelli, A.; Chini, M. G.; Canonico, P. L.; Sorba, G.; Bifulco, G.; Tron, G. C.; Genazzani, A. A. 2010, A novel potent nicotinamide phosphoribosyltransferase inhibitor synthesized via click chemistry, Journal of Medicinal chemistry, 53, 616-623; b) Moses, J. E.; Moorhouse, A. D. 2007, The growing applications of click chemistry, Chemical Society Reviews, 36, 1249-1262.

[5] Wang, M.; Xia, Y.; Fan, Y.; Rocchi, P.; Qu, F.; Iovanna, J. L.; Peng, L. 2010, A novel arylethynyltriazole acyclonucleoside inhibits proliferation of drug-resistant pancreatic cancer cells, Bioorganic \& Medicinal Chemistry Letters, 20, 5979-5983.

[6] Youcef, R. A.; Santos, M. D.; Roussel, S.; Baltaze, J.-P.; Lubin-Germain, N.; Uziel, J. 2009, Huisgen Cycloaddition Reaction of C-Alkynyl Ribosides under Micellar Catalysis: Synthesis of Ribavirin Analogues, The Journal of Organic Chemistry, 74, 4318-4323. 